http://dx.doi.org/10.18778/1429-3730.40.02

\author{
Agnieszka Ciechelska*
}

Malgorzata Maria Pol**

\title{
OSZACOWANIE EFEKTÓW ZEWNĘTRZNYCH STOSOWANIA WYBRANYCH OZE W ELEKTROCIEPLOWNI, W KONTEKŚCIE SPELNIANIA CELÓW ŚRODOWISKOWYCH
}

\begin{abstract}
Estimating the effects of external application of selected renewable energy source using in the power plant, in the context of meeting the environmental objectives Increasing problems associated with greenhouse gas emissions, resource management, and increasing the amount of municipal waste generated, causing tightening of environmental regulations, and these in turn need to search for new solutions. One of the biggest $\mathrm{CO}_{2}$ emitters and consumers of non-renewable resource is the CHP sector, which is using the coal. Regulations impose a partial replacement of this material by renewable energy sources by running the stimulus instruments of environmental policy. However, analyzing the available resources in a given area (biomass, waste, fossil resources) and the externalities generated by the energy use of these resources should be differentiated support systems. They should be addressed to the resource that will provide energy security and least shall be covered by the environment and, therefore, society. The article analyzes the potential energy use of willow grown on the premises and available municipal waste produced in the provinces of Lower Silesia, Silesia, Greater Poland, Lesser Poland and Opole. The obtained values of externalities suggest that the benefits derived from the replacement of coal, municipal waste are much higher (sometimes several dozen) than the replacement energy willow. Additionally allows to deal with the problem of the waste management and avoid high penalties for non-compliance of the system to EU requirements. This is an indication for policy-makers, so that should shape the legislation to create incentives to adapt CHP sector for municipal waste incineration. In this way, it will be easier to meet environmental objectives in the area of $\mathrm{CO}_{2}$ emissions and waste management.
\end{abstract}

Key words: Alternative Energy source (municipality waste,biomass), valuation of environmental effects

JEL clasification: Q42, Q41, Q51

* Dr, Uniwersytet Ekonomiczny we Wrocławiu.

** Dr, Kogeneracja S.A. 


\section{Wprowadzenie}

Powszechnie uważa się, że stosowanie ekologicznych nośników energii spełnia przyjęte założenia środowiskowe (głównie redukcja emisji gazów cieplarnianych oraz wykorzystania zasobów nieodnawialnych) i jest opłacalne ekonomicznie, a więc jest społecznie korzystne. Brak jest jednak badań całkowitych kosztów takich rozwiązań, z uwzględnieniem kosztów środowiskowych i społecznych.

W artykule Autorki podjęły próbę identyfikacji, oszacowania oraz wyceny efektów społecznych i środowiskowych, zastępowania węgla kamiennego, biomasą nieleśną oraz odpadami komunalnymi. W swoich analizach uwzględnily lokalne parametry nośników energii, mogące mieć wpływ na zróżnicowanie wyników. Do wyliczeń przyjęto uśrednione parametry dla biomasy nieleśniej i odpadów komunalnych z następujących województw: dolnośląskiego, śląskiego, wielkopolskiego, małopolskiego i opolskiego. Skład morfologiczny odpadów komunalnych przyjęto na podstawie Wojewódzkich Planów Gospodarki Odpadami, a biomasy nieleśnej na podstawie uzyskanych wyników z laboratorium elektrociepłowni Kogeneracja S.A.

Celem artykułu jest oszacowanie pełnego kosztu stosowania wybranych nośników energii w sektorze energetycznym i porównanie opłacalności zastępowania węgla kamiennego, jako paliwa „nieekologicznego”, paliwem „ekologicznym” - biomasą nieleśną i odpadami komunalnymi. Hipoteza jest następująca: efekty zewnętrzne zastępowania paliwa kopalnego - węgla kamiennego, paliwami ekologicznymi-biomasą nieleśną oraz odpadami komunalnymi, znacznie ograniczają społeczną opłacalność stosowania tych rozwiązań w sektorze energetycznym. Tym samym wszelkie nakazy stosowania paliwa „ekologicznego”, zwłaszcza biomasy, w procesach produkcyjnych w energetyce nie mają podstaw ekonomicznych i są nieracjonalne społecznie.

W ostatnich latach nasiliły się tendencje do powszechnego wykorzystania odnawialnych źródeł energii oraz oszczędzania energii. Jednym z przejawów tych trendów jest stosowanie ekologicznych nośników energii w energetyce zawodowej. W Polsce jest to niemal zupełnie nowy obszar, gdyż krajowy sektor energetyczny, a zwłaszcza podsektor elektroenergetyczny, nadal do produkcji energii wykorzystuje w ponad 90\% węglowe kopalne surowce energetyczne (węgiel kamienny, węgiel brunatny, ropę naftową czy gaz ziemny) ${ }^{1}$ Pozostałe $10 \%$ to najczęściej biomasa leśna i nieleśna - uprawy energetyczne i biodegradowalne odpady z przemysłu rolno-spożywczego. Odpady komunalne niemal w ogóle nie są wykorzystywane w tym celu. Kierunki polityki państwa i Unii Europejskiej wskazują, że zastępowanie paliw kopalnych innymi nośnikami energii

${ }^{1}$ Opracowanie własne na podstawie GUS: Energia ze źródeł odnawialnych w 2012 roku, Warszawa 2013, tabela 3, s. 23. 
w sektorze energetycznym powinno się rozwijać. Dyskusyjne jest natomiast jaki nośnik energii będzie najkorzystniejszy jako zamiennik węgla. Powszechnie analizowane rachunki opłacalności ekonomicznej uwzględniają koszty inwestycyjne i eksploatacyjne. Brak jest analizy kosztów zewnętrznych. Uwzględnienie ich w szacunkach daje pełen obraz kosztów społecznych, a więc z uwzględnieniem skutków środowiskowych i społecznych, danego rozwiązania. Takie analizy powinny stanowić podstawę dla decydentów dla konstruowania zapisów prawnych, które chroniłyby interes społeczny. W niektórych przypadkach dają też lepszy obraz korzyści i/lub kosztów jakie należy ponieść w dłuższym okresie czasu przy realizacji danego przedsięwzięcia.

\section{Ramy prawne - cele środowiskowe}

Zastępowanie paliw kopalnych, odnawialnymi ma przede wszystkim na celu, ograniczyć emisję gazów cieplarnianych oraz zmniejszyć wykorzystanie zasobu nieodnawialnego, jakim jest węgiel (czy gaz), i zachować go dla przyszłych pokoleń. Stąd „zamienniki” muszą być zasobem odnawialnym oraz generować mniejsze oddziaływanie na środowisko niż wykorzystywanie paliw kopalnych. Kierunki te zostały potwierdzone przez politykę państwa oraz odpowiednie krajowe i unijne akty prawne. Jedną z podstawowych regulacji unijnych dotyczących energetyki jest Dyrektywa 2004/8/WE², która ma na celu zwiększenie efektywności energetycznej i poprawę bezpieczeństwa dostaw energii poprzez stworzenie ram dla wspierania i rozwoju produkcji ciepła i energii elektrycznej w układzie kogeneracji (CHP) o wysokiej wydajności opartej na zapotrzebowaniu na ciepło użytkowe i oszczędnościach w energii pierwotnej na wewnętrznym rynku energii. Zgodnie z nowymi celami Unii Europejskiej, Polska do 2020 r. powinna osiągnąć 15\% udział energii elektrycznej z OZE w zużyciu energii elektrycznej brutto ${ }^{3}$. Dążenie do osiągnięcia tego progu zostało potwierdzone w Krajowym Planie Działania w zakresie energii ze źródeł odnawialnych ${ }^{4}$.

Zgodnie z priorytetami zawartymi w Polityce energetycznej Polski do $2030^{5}$ roku w odniesieniu do odnawialnych źródeł energii (OZE) i CHP, rozwój

2 Dyrektywa 2004/8/WE Parlamentu Europejskiego i Rady z dnia 11 lutego 2004 r. w sprawie wspierania kogeneracji w oparciu o zapotrzebowanie na ciepło użytkowe na rynku wewnętrznym energii oraz zmieniająca dyrektywę 92/42/EWG.

${ }^{3}$ Dyrektywa Parlamentu Europejskiego i Rady 2009/28/WE z dnia 23 kwietnia 2009 r. w sprawie promowania stosowania energii ze źródeł odnawialnych zmieniającej i w następstwie uchylającej dyrektywy 2001/77/WE oraz 2003/30/WE.

${ }^{4}$ Krajowy Plan Działania w zakresie energii ze źródeł odnawialnych, 7 grudnia 2010.

${ }^{5}$ Załącznik do uchwały nr 157/2010 Rady Ministrów z dnia 29 września 2010 r., Polityka energetyczna Polski do 2030. 
i wykorzystanie odnawialnych źródeł energii, w tym biopaliw ma wynieść 15\% (10\% do roku 2020). Do roku 2020 przewiduje się dwukrotny wzrost produkcji energii elektrycznej wytwarzanej w technologii wysokosprawnej kogeneracji w porównaniu do poziomu z roku 2006 (cel zawarty w priorytecie dotyczącym poprawy efektywności energetycznej). Istotnymi celami są również ograniczenie oddziaływania energetyki na środowisko i wzrost bezpieczeństwa energetycznego. Wykorzystanie OZE i obowiązek ograniczenia emisji gazów cieplarnianych został poparty wprowadzeniem narzędzi polityki ekologicznej. Sektor energetyczny bierze udział w rynku uprawnień zbywalnych do emisji $\mathrm{CO}_{2}{ }^{6}$ oraz może pozyskać zielone certyfikaty za produkcję zielonej energii ${ }^{7}$. zwiększające opłacalność jej produkcji. Rynkowy charakter tych narzędzi pozwala na ograniczenie kosztów zaostrzania przepisów środowiskowych. W rynku uprawnień zbywalnych nie biorą udziału instalacje spalające odpady komunalne i paliwa alternatywne ${ }^{8}$. Zatem instalacje emitujące $\mathrm{CO}_{2}$ ze spalania odpadów nie muszą się ubiegać o uprawnienia do emisji.

Energia uzyskana ze spalania wierzby energetycznej oraz częściowo z odpadów może być uznana jako energia ze źródeł odnawialnych ${ }^{9}$. Produkcja energii odnawialnej z odpadów może dotyczyć tylko niesegregowanych odpadów komunalnych, dla których wykazano poprzez badania, że zawartość części biodegradowalnych przekracza w nich 42\%. Tym samym energia ze spalania RDF nie może być zakwalifikowana jako energia odnawialna. Zakłady elektroenergetyczne wytwarzając energię ze źródeł odnawialnych uzyskują prawa majątkowe w postaci świadectwa pochodzenia energii (zielone certyfikaty). Obejmują one tylko energię elektryczną wytworzoną z OZE ${ }^{10}$.

W zakresie ,zamienników” paliw kopalnych istnieje cały szereg uregulowań, których spełnienie wpływa na wartość efektów zewnętrznych, gdyż

${ }^{6}$ Ustawa z dnia 28 kwietnia 2011 r. o systemie handlu uprawnieniami do emisji gazów cieplarnianych (Dz.U. 2011, Nr 122, poz. 695).

${ }^{7}$ Rozporządzenie Ministra Gospodarki z dnia 18 października 2012 r. w sprawie szczegółowego zakresu obowiązków uzyskania i przedstawienia do umorzenia świadectw pochodzenia, uiszczenia opłaty zastępczej, zakupu energii elektrycznej i ciepła wytworzonych w odnawialnych źródłach energii oraz obowiązku potwierdzania danych dotyczących ilości energii elektrycznej wytworzonej w odnawialnym źródle energii Dz.U. 2012, Nr 0, poz. 1229, Rozporządzenie Ministra Gospodarki z dnia 4 maja 2007 r. w sprawie szczegółowych warunków funkcjonowania systemu elektroenergetycznego (Dz.U. 2007, Nr 93, poz. 623 ze zm.).

8 Załącznik B, Ustawa z dnia 28 kwietnia 2011 r. o systemie handlu uprawnieniami do emisji gazów cieplarnianych (Dz.U. 2011, Nr 122, poz. 695).

${ }^{9}$ Art. 159.1. ustawy o odpadach z dnia 8 stycznia 2013 r., Rozporządzenie Ministra Środowiska z dnia 2 czerwca 2010 r. w sprawie szczegółowych warunków technicznych kwalifikowania części energii odzyskanej z termicznego przekształcania odpadów komunalnych (Dz.U.10.117.788).

${ }_{10}$ M. Brando, A. Cylwik, F. Elżanowski, A. Kucińska, M. Kulesa, Dostosowanie systemu wsparcia dla energii elektrycznej pochodzacej z odnawialnych źródet energii do zmian zachodzacych kosztach wytwarzania energii paliw kopalnych, Warszawa: Ministerstwo Gospodarki, 2009, s. 15. 
pozwala na dostosowanie się do wymogów unijnych i uniknięcie ewentualnych sankcji. W artykule, analizie zostanie poddane wykorzystanie wierzby energetycznej oraz odpadów komunalnych. Te ostatnie stanowią w Polsce ogromny ciągle nierozwiązany problem. Aktualnie polska gospodarka odpadami znajduje się w fazie intensywnej przebudowy i dostosowania do wymogów unijnych, stąd szereg nowych obowiązków w tym zakresie. Według Krajowego Planu Gospodarki Odpadami ${ }^{11}$, mechaniczno-biologiczne przetwarzanie (MBP) odpadów preferowane jest, lub będzie, w regionach obejmujących powyżej 120 tys. mieszkańców. Zakłady MBP nie są instalacjami ostatecznego zagospodarowania odpadów, lecz ich przygotowania do odzysku lub unieszkodliwiania m.in. w instalacjach termicznego unieszkodliwiania. Produktem działania MBP jest paliwo alternatywne (RDF), którego w Polsce praktycznie jedynym odbiorcą paliwa są cementownie. W elektrowniach i elektrociepłowniach RDF nie jest wykorzystywany ze względu na wymagania formalno-prawne ustanowione dla procesu spalania/współspalania odpadów, emisji zanieczyszczeń i parametrów popiołu $^{12}$. W Polsce potencjał produkcji RDF, szacuje się na 4,5-6 mln Mg/rok. Takiej ilości nie jest w stanie wykorzystać przemysł cementowy. Konieczne jest tu zainteresowanie ze strony sektora elektroenergetycznego, ale wymaga to znacznych nakładów inwestycyjnych w celu dostosowania do wymogów prawnych ${ }^{13}$. Do najważniejszych regulacji uzasadniających wykorzystanie odpadów komunalnych w celach energetycznych, należą:

- uwzględnienie hierarchii postępowania z odpadami (redukcja wytwarzania, selektywna zbiórka, recykling, spalanie) i obowiązek selektywnej zbiórki co najmniej papieru, metali, tworzyw sztucznych i szkła, jako podstawowego warunku zapewnienia wysokiej jakości recyklingu oraz promowanie selektywnego zbierania bioodpadów i odpowiedniego ich przetwarzania,

- przygotowanie do ponownego użycia i recyklingu co najmniej 4 frakcji odpadów pochodzących z gospodarstw domowych (w 2020 r. $-50 \%)^{14}$,

${ }^{11}$ Krajowy plan gospodarki odpadami 2014, załącznik do Uchwały Nr 217 Rady Ministrów z dnia 24 grudnia 2010 r. w sprawie „Krajowego planu gospodarki odpadami 2014”, Monitor Polski $\mathrm{Nr} 101$, poz. 1183.

12 Rozporządzenie Ministra Gospodarki z dnia 21 marca 2002 r. w sprawie wymagań dotyczących prowadzenia procesu termicznego przekształcania odpadów z późn. zm. (Dz.U. 2002, Nr 37, poz. 339), Rozporządzenie Ministra Środowiska z dnia 4 listopada 2008 r. w sprawie wymagań w zakresie prowadzenia pomiarów wielkości emisji oraz pomiarów ilości pobieranej wody (Dz.U. 2008, Nr 206, poz. 1291), Rozporządzenie Ministra Środowiska z dnia 22 kwietnia 2011 r. w sprawie standardów emisyjnych z instalacji (Dz.U. 2011, Nr 95, poz. 558).

13 Dyrektywa Parlamentu Europejskiego i Rady 2000/76/WE z dnia 4 grudnia 2000 r. w sprawie spalania odpadów (tzw. dyrektywa spaleniowa) (Dz.Urz. WE L 332 z 28.12.2000, s. 91, z późn. zm.).

${ }^{14}$ Dyrektywa Parlamentu Europejskiego i Rady 2008/98/WE z dnia 19 listopada 2008 r. w sprawie odpadów oraz uchylająca niektóre dyrektywy (Dz.Urz. UE L 312 z 22.11.2008, s. 3). 
- redukcja składowania odpadów komunalnych ulegających biodegradacji - nie więcej niż 35\% odpadów komunalnych ulegających biodegradacji wytworzonych w 1995 r.) i zakaz składowania odpadów niespełniających kryteriów dopuszczania do składowania ${ }^{15}$.

Regulacje te znajdują swoje odzwierciedlenie w przepisach prawa krajowego, m.in. w Krajowym Planie Gospodarki Odpadami ${ }^{16}$ oraz w ustawie o odpadach ${ }^{17}$.

\section{Technologiczne możliwości zamiany paliw kopalnych na odnawialne}

Wobec przepisów prawnych promujących stosowanie OZE, sektor energetyczny w Polsce zaczyna poszukiwać nowych rozwiązań. Najczęściej decyduje się na produkcję zielonej energii poprzez przystosowanie istniejących instalacji do współspalania węgla kopalnego z biomasą. Wykorzystywanie odpadów jako nośnika energii nie jest w Polsce obecne. W Polsce głównym źródłem zielonej energii była do niedawna biomasa leśna oraz, w niewielkim stopniu, uprawy energetyczne. Jednak zapotrzebowanie sektora energetycznego na drewno surowe spowodowało zubożenie obszarów zielonych i problemy sektora meblarskiego. Dlatego wykorzystanie drewna pełnowartościowego jako zielonego paliwa zostało prawnie ograniczone ${ }^{18}$.

Innym źródłem biomasy w Polsce są uprawy energetyczne. Najbardziej rozpowszechniona jest uprawa wierzby energetycznej. Jednak funkcjonowanie takiej uprawy niesie ze sobą spore koszty i ryzyko. Pod ich uprawy przeznaczane są duże areały ziemi rolnej. Opłacalne ekonomiczne staja się uprawy o powierzchni powyżej 20 ha $^{19}$. Dlatego tez jest to jeden z czynników hamujących rozwój tych plantacji w Polsce. Do głównych zagrożeń należy zaliczyć istotne ryzyko nie przyjęcia się stosunkowo drogich sadzonek w pierwszych dwóch latach uprawy, czy zniszczenie uprawy w wyniku anomalii pogodowych jak grad, powódź, czy silny mróz w okresie wegetacyjnym roślin. Uprawa

${ }^{15}$ Dyrektywa Rady 1999/31/WE z dnia 26 kwietnia 1999 r. w sprawie składowania odpadów (Dz.Urz. WE L 182 z 16.07.1999, s. 1, z późn. zm.).

${ }^{16}$ Krajowy Plan Gospodarki Odpadami 2014, Uchwała Rady Ministrów Nr 217 z dnia 24 grudnia 2010 r. w sprawie „Krajowego planu gospodarki odpadami 2014”, Monitor Polski Nr 101, poz. 1183.

${ }_{17}$ Ustawa o odpadach z dnia 14 grudnia 2012 r. (Dz.U. 2013, poz. 21).

18 Rozporządzenie Ministra Gospodarki z dnia 18 października 2012 r. w sprawie szczegółowego zakresu obowiązków uzyskania i przedstawienia do umorzenia świadectw pochodzenia, uiszczenia opłaty zastępczej, zakupu energii elektrycznej i ciepła wytworzonych w odnawialnych źródłach energii oraz obowiązku potwierdzania danych dotyczących ilości energii elektrycznej wytworzonej w odnawialnym źródle energii, Dz.U. Nr 0, poz. 1229, w § 6 ust. 2.

19 J. Skorek, J. Kalina, Ocena techniczno-ekonomiczna możliwości realizacji projektów energetycznego wykorzystania biomasy w Polsce, Instytut Doskonalenia Wiedzy o Rynku Energii, IDWE Warszawa 2009, s. 13. 
do celów energetycznych nadaje się dopiero po upływie trzech lat, stąd kolejne ryzyko - konieczność zamrożenia kapitału na ten okres. Zagrożenia te wymagają również odpowiednich zabezpieczeń ze strony elektrociepłowni, głównie w postaci dywersyfikacji źródeł dostaw paliwa. Stosowanie paliwa z upraw energetycznych wymaga odpowiedniego odpowiednich warunków technologicznych. Surowa wierzba zawiera ok. 50\% wilgoci, ma stosunkowo dużą objętość i ciężar oraz stosunkowo niską wartość opałową. Parametry te poprawiają się w procesie suszenia. Ze względu na szybki wzrost pleśni i grzybów na tym materiale, konieczne jest suszenie w terenie otwartym lub specjalnych suszarniach. Właściwości te powodują stosunkowo wysoki koszt transportu i konieczność dysponowania terenem o dużej powierzchni. Innym zagrożeniem technologicznym jest szlakowania rusztów kotłów, co może spowodować ogromne dodatkowe koszty z tytułu przestojów i napraw urządzeń energetycznych. Dodatkowym elementem osłabiającym atrakcyjność upraw energetycznych jest zniesienie od 2010 r. dopłat unijnych do zakładania takich plantacji (45 euro/ha).

Innym nośnikiem energii, możliwym do wykorzystania przez ciepłownie jest biomasa nieleśna, czyli odpady z rolnictwa i przemysłu przetwórczego. Jednak poważnym problemem jest zróżnicowanie wilgotności poszczególnych rodzajów biomasy, co wymaga od inwestora dodatkowych nakładów związanych $\mathrm{z}$ ujednoliceniem materii $\mathrm{w}$ celu prowadzenia stabilnego procesu spalania cząsteczek. Pociąga to również za sobą dodatkowe koszty transportu, magazynowania, czy obróbki na miejscu. Drugim ważnym problemem dla wykorzystania biomasy nieleśnej przez sektor energetyczny jest sezonowość jej powstawania. Ilość takiej biomasy, możliwej do wykorzystania w energetyce jest jednak ograniczona, ze względu na wykorzystywanie przez rolników jako pożywienie dla zwierząt hodowlanych. Wykorzystanie tych odpadów przez energetykę doprowadziłoby do konieczności poszukiwania przez rolników innych sposobów wykarmiania bydła. Prawdopodobnie część gruntów rolnych musiałoby zostać przeznaczone na produkcję pożywienia dla zwierząt, a nie dla ludzi.

Kolejnym nośnikiem energii są odpady komunalne, których wartość energetyczna jest porównywalna $\mathrm{z}$ wartością energetyczną biomasy nieleśnej. Wykorzystanie takiego paliwa wymaga jego homogenizacji i wysuszenia, ale te procesy są prowadzone obecnie w instalacjach MBP. Najważniejszym argumentem za stosowaniem tego paliwa, jest stale rosnąca ilość wytwarzanych odpadów komunalnych. Wykorzystanie tego paliwa pozwoliłoby na wywiązanie się z obowiązków, nałożonego na kraje członkowskie UE (wymienionych powyżej). Dotychczas Polska słabo radzi sobie z tym problemem. Poziom uzyskania energii pochodzącej z odpadów komunalnych w 2011 roku wynosił $0,4 \%{ }^{20}$.

${ }^{20}$ Opracowanie własne na podstawie GUS: Energia ze źródeł odnawialnych w 2012 roku, Warszawa 2013, tabela 3, s. 23. 
Przy identyfikacji efektów zewnętrznych uwzględniono takie efekty, które w największym stopniu wpisują się w cele wyrażone w przepisach prawnych. Do najważniejszych zaliczono emisję $\mathrm{CO}_{2} \mathrm{i}$ jej konsekwencje, wykorzystanie OZE i redukcję wykorzystania zasobów nieodnawialnych, inne oddziaływania środowiskowe najbardziej znaczące dla danego nośnika energii, jak np. wykorzystanie wody do podlewania, czy emisja gazu składowiskowego. Kalkulacja efektów zewnętrznych jest niezbędna decydentom przy tworzeniu prawa, a w ten sposób porządku społecznego, zapewniającego jak najwyższą jakość życia mieszkańcom. Dlatego też w wycenie efektów przyjęto jako cenę jednostkową stawki opłaty za korzystanie ze środowiska. Przyjęto założenie, że opłaty te uwzględniają efekty zewnętrzne, a więc dają określony obraz wartości dóbr środowiskowych. W artykule szacowano poszczególne efekty zewnętrzne w odniesieniu do zasobów i warunków charakterystycznych dla pięciu województw: dolnośląskiego, śląskiego, małopolskiego, wielkopolskiego i opolskiego. Na obszarze analizowanych pięciu województw istnieje możliwość przeznaczenia 6000 ha gruntu pod uprawy wierzby energetycznej (bez uwzględniania podziałów właścicielskich) oraz około 4,5-5 mln Mg odpadów komunalnych rocznie, które mogłyby zostać wykorzystane energetycznie.

\section{Oszacowanie kosztów zewnętrznych zastosowania wierzby energetycznej jako źródła paliwa}

Z potencjalnie dostępnego areału można pozyskać około $60000 \mathrm{Mg}$ surowego drewna wierzby. Przyjmując wartość opałową wierzby energetycznej na poziomie $10 \mathrm{GJ} / \mathrm{Mg}$, z tego areału można wyprodukować 600 tys. GJ $\mathrm{w}$ ciągu roku. Cała wyprodukowana w ten sposób energia jest energią zieloną. Przyjęto, że plantacja wierzby będzie zakładana na najsłabszych glebach, będących w posiadaniu plantatorów. Dlatego też pominięto koszt zakupu ziemi. Koszt sadzonek wynosi około $20000 \mathrm{zł} / \mathrm{ha}^{21}$. Wymóg prowadzenia upraw wielkoobszarowych oznacza tworzenie monokultur i ograniczanie bioróżnorodności, co stanowi koszt środowiskowy. Koszt prowadzenia plantacji to około $15000 \mathrm{zł} / \mathrm{ha} / \mathrm{rok}^{22}$. Koszty te obejmują podlewanie, odchwaszczanie, opryski i ewentualne dosadzenia. Większość tych kosztów pochłania koszt zakupu wody, której plantacja potrzebuje aż 10000000 1/ha/rok. Woda ta stanowi utracony zasób. Wartość tego zasobu ma swoje odzwierciedlenie w opłacie za wodę, w postaci opłaty za pozyskanie wody, płaconej przez zakład produkujący

${ }^{21} \mathrm{http} / / / \mathrm{www} . z a s a d . f r i k o . p l /$.

22 J. Skorek, J. Kalina, Ocena techniczno-ekonomiczna możliwości realizacji projektów energetycznego wykorzystania biomasy w Polsce, Instytut Doskonalenia Wiedzy o Rynku Energii, IDWE Warszawa 2009, s. 13. 
wodę. Przyjmując, że cena wody ${ }^{23}$ wynosi $1,2 \mathrm{z} z / \mathrm{m}^{3}$, roczny koszt podlewania 1 ha wynosi $12000 \mathrm{zł}$. W uprawie wierzby energetycznej możliwe jest wykorzystywanie osadów ściekowych, za zagospodarowanie których, właściciel plantacji otrzymuje wynagrodzenie w wysokości $20-135$ zł/Mg osadów ${ }^{24}$. Dawkowanie osadów wynosi do $250 \mathrm{Mg}$ suchej masy/ha w pierwszych trzech latach uprawy, a następnie do $10 \mathrm{Mg}$ suchej masy/ha ${ }^{25}$. W ciągu 30 lat funkcjonowania plantacji właściciel może wykorzystać maksymalnie $34 \mathrm{Mg}$ osadów/ ha/rok. Ze względu na restrykcyjne wymogi dotyczące jakości takich osadów oraz brak konieczności stosowania maksymalnych dawek osadów, do dalszych wyliczeń przyjęto: dawka roczna $20 \mathrm{Mg} / \mathrm{ha}$, cena przyjęcia $20 \mathrm{z} / \mathrm{Mg}$. Przy tych założeniach, dla analizowanego obszaru przychód z tytułu wykorzystania osadów wynosi $2,4 \mathrm{mln}$ zł/rok. Pomijanym często elementem w rachunkach opłacalności, jest koszt likwidacji plantacji wierzby i rekultywacji po niej terenu. Szacuje się, że koszty takie są porównywalne z likwidacją dorosłego lasu i wynoszą od 8 do 10 tys. zł/ha ${ }^{26}$.

W rachunku kosztów należy jeszcze uwzględnić koszty związane z procesem produkcji energii z wierzby. Utrudnieniem jest duża zawartość chloru w drewnie wierzby, co w połączeniu z wodą i pod wpływem wysokiej temperatury $\mathrm{w}$ trakcie spalania $\mathrm{w}$ kotłach energetycznych, tworzy parową mieszankę kwasu solnego. Powoduje to błyskawiczną korozję kotłów niskotemperaturowych, co podnosi koszt pozyskania takiej energii.

Kolejnym efektem zewnętrznym jest ograniczenie wytwarzania tlenu i absorpcji $\mathrm{CO}_{2} \mathrm{w}$ procesie fotosyntezy poprzez wycinanie roślin. Pierwotnie, tereny przeznaczone pod uprawę są zwykle porośnięte krzewami (a niekiedy drzewami) i inną roślinnością. Średnio dwunastoletnie drzewo absorbuje odpowiednio jedną tonę ditlenku węgla na każdy metr sześcienny drzewostanu i produkuje przy tym $727 \mathrm{~kg}$ tlenu ${ }^{27} . \mathrm{Z} 1 \mathrm{~m}^{2}$ powierzchni liściowej dwunastoletnich drzew i krzewów dostaje się do powietrza atmosferycznego w ciągu okresu wegetacyjnego, od 0,5 do ponad $1 \mathrm{~kg}$ czystego tlenu ${ }^{28}$. Zakładając, że połowa analizowanego obszaru (6000 ha) jest porośnięta krzewami lub drzewami,

${ }^{23}$ Koszt $\mathrm{m}^{3}$ wody $\mathrm{z}$ gruntu stanowi około $40 \%$ kosztu wody wodociągowej, tj. $1,20 \mathrm{z} / \mathrm{m}^{3}$. (Koszt zakupu $\mathrm{m}^{3}$ wody wynosi 3 zł jest to wartość uśredniona $\mathrm{z}$ kilku stacji uzdatniania wody dla analizowanego obszaru).

${ }^{24}$ www.wierzbaenergetyczna.info.

${ }_{25}$ A. Sieciechowicz, Osady ściekowe na plantacji wierzby energetycznej, Zeszyty Naukowe Uniwersytetu Zielonogórskiego nr 141, Inżynieria środowiska 21, Zielona Góra 2011.

${ }^{26}$ W. Majtkowski, Potencjał upraw energetycznych, badania własności i standaryzacji biopaliw stałych, materiały seminaryjne, Europejskie Centrum Energii Odnawialnej, Warszawa 30 czerwca 2003 r., s. 14.

27 A. Lasiewicz, Oczyszczająca rola drzew, Program klimatyczny Polskiej Zielonej Sieci 2009 finansowany ze środków Komisji Europejskiej.

${ }^{28}$ Tamże. 
to w ciągu roku są one w stanie wyprodukować od 15000 do $30000 \mathrm{Mg}$ tlenu i pochłonąć od około 21500 do niemal $43000 \mathrm{Mg}$ ditlenku węgla ${ }^{29}$. Rośliny energetyczne ze względu na stosunkowo niewielką powierzchnię liści i krótki okres życia, mają te zdolności nieporównywalnie mniejsze, ale pokrywają równomiernie cały analizowany obszar a plantacje funkcjonują przez 25-30 lat. Dlatego do analizy emisji i absorpcji przyjęto takie wielkości, jak gdyby obszar 6000 ha był w połowie porośnięty dwunastoletnimi drzewami. Zatem w trakcie wzrostu taka plantacja może pochłonąć do $41200 \mathrm{Mg}$ ditlenku węgla i wyemitować do $30000 \mathrm{Mg}$ tlenu. Spalanie jej powoduje emisję do powietrza $\mathrm{CO}_{2}$ dokładnie w takiej samej wysokości, stąd bilans emisji jest zerowy. Do dalszych obliczeń przyjęto wartości średnie: emisja $\mathrm{O}_{2}$ wynosi $22500 \mathrm{Mg}$, a absorpcja $\mathrm{CO}_{2}, 31000 \mathrm{Mg}$. Dla wyprodukowania tej samej ilości energii co z $60000 \mathrm{Mg}$ zielonego paliwa, należy zużyć $28600 \mathrm{Mg}$ węgla kamiennego o wartości opałowej $21 \mathrm{GJ} / \mathrm{Mg}$, czemu towarzyszy emisja $\mathrm{CO}_{2}$ w wysokości $56300 \mathrm{Mg}^{30}$. Zatem taka uprawa redukuje emisję $\mathrm{CO}_{2}$ o $25300 \mathrm{Mg}$, co pozwala uzyskać nadwyżkę uprawnień zbywalnych o wartości $0,66 \mathrm{mln}$ zł.

Elektrociepłownie emitując $\mathrm{CO}_{2}$ mają obowiązek posiadać uprawnienia do emisji na całą wielkość emisji. Różnice są bilansowane poprzez zakup lub sprzedaż na rynku uprawnień zbywalnych. Cenę uprawnień przyjęto na poziomie 6 euro/ $\mathrm{MgCO}_{2}$ ekwiwalentnego ${ }^{31}$. Wartość efektu zewnętrznego powodowanego przez emisję $\mathrm{CO}_{2}$ wyliczono właśnie przy zastosowaniu tej ceny. Wartość uprawnień zbywalnych, niezbędnych przy spalaniu węgla, wynosi 351600 euro/rok tj. około 1,4 mln zł/rok. Natomiast przy spalaniu wierzby koszt ten wynosi około $1 \mathrm{mln}$ zł/rok ${ }^{32}$. Zatem oszczędność kosztów przy stosowaniu wierzby energetycznej wynosi $0,4 \mathrm{mln}$ zł/rok. Elektociepłownie wykorzystujące OZE mogą uzyskać prawa majątkowe w postaci zielonych certyfikatów, które mogą być przedmiotem sprzedaży na Towarowej Giełdzie Energii. Tym samym jest to rodzaj wsparcia dla produkcji energii ze źródeł odnawialnych. Jednak certyfikaty te mogą być przyznawane jedynie dla wytworzonej energii elektrycznej. Zgodnie z zapisami, producenci energii elektrycznej wytworzonej w wysokosprawnej kogeneracji w jednostkach opalanych węglem, muszą wytwarzać w roku 2014-2018 - 23,2\% energii z OZE ${ }^{33}$. Do dalszych wyliczeń przyjęto, że w układzie kogeneracyjnym $40 \%$ wytworzonej energii to energia

${ }^{29}$ Wyliczenia własne na podstawie wcześniejszych danych.

${ }^{30}$ Wartości opałowe (WO) i wskaźniki emisji $\mathrm{CO}_{2}$ (WE) w roku 2011 do raportowania w ramach Wspólnotowego Systemu Handlu Uprawnieniami do Emisji za rok 2014, KOBIZE, grudzień 2013.

31 Do wyliczeń przyjęto cenę EUA 6 euro/Mg. Ceny EUA kształtują się w granicach około 5,72 eur/Mg w grudniu 2012 do około 6,3 euro/Mg we wrześniu 2014. Ceny ze strony http://www. handel-emisjami-co2.cire.pl.

${ }^{32}$ Przyjęto kurs 1 euro $=4$ zł.

${ }^{33}$ Ustawa Prawo energetyczne 2014. 
elektryczna, a 50\% to energia cieplna. Przyjmując, że elektrociepłownia spala wyłącznie biomasę, tylko za 40\% wytworzonej energii może uzyskać zielone certyfikaty (świadectwa pochodzenia energii). Cena za zielone certyfikaty w okresie od września 2013 do września 2014 r. wahała się między 177,69 zł/ MWh do 250,47 zł/MWh ${ }^{34}$. Do dalszych wyliczeń przyjmuję średnią wartość ceny $214,08 \mathrm{zl} / \mathrm{MWh}$. Przyjmując, że spalana jest wyłącznie biomasa, to przy założeniu, że $40 \%$ produkcji stanowi energia elektryczna, z 600000 GJ energii rocznie można wyprodukować 240000 GJ zielonej energii elektrycznej, co stanowi $72000 \mathrm{MWh} /$ rok. A więc można uzyskać zielone certyfikaty o wartości $17,3 \mathrm{mln}$ złotych/rok.

Korzyści wykorzystania biomasy dotyczą również mniejszej ilości popiołów. Ilość popiołów ze spalania wierzby energetycznej szacuje się na poziomie $1,2-$ $3,5 \%$ jej masy podczas, gdy ze spalania węgla kamiennego, na poziomie $22 \%{ }^{35}$. Oznacza to, że w procesie spalania wierzby powstanie średnio $1400 \mathrm{Mg} /$ rok popiołów, a po spaleniu węgla $6300 \mathrm{Mg}$ popiołów rocznie. Czyli wykorzystanie wierzby pozwala zredukować ilość popiołów o $4890 \mathrm{Mg} /$ rok. Cenę za emisję $1 \mathrm{Mg}$ popiołów ze spalania węgla, przyjęto na poziomie 19,46 zł/Mg, jako stawkę opłaty za korzystanie ze środowiska ${ }^{36}$.

Ponadto należy uwzględnić różnice pomiędzy ceną zakupu obu paliw. Cena zakupu węgla kamiennego wynosi $320^{37}-350^{38} \mathrm{z} / \mathrm{Mg}$. Do dalszych obliczeń przyjmuję średnią cenę 335 zł/Mg. Cena zakupu wierzby energetycznej wynosi $220-$ $260 \mathrm{zz} / \mathrm{Mg}^{39}$ (średnio $240 \mathrm{zt} / \mathrm{Mg}$ ). Dla wyprodukowania tej samej ilości energii należy spalić $60000 \mathrm{Mg}$ wierzby energetycznej lub $28600 \mathrm{Mg}$ węgla kamiennego. Oznacza to, że zakup wierzby jest droższy o $4,8 \mathrm{mln}$ zł/rok. Do tego należy jeszcze doliczyć wyższe koszty transportu, ze względu na większą masę i objętość paliwa konieczną do dostarczenia do zakładu energetycznego.

W tabeli 1 przedstawiono łączne koszty produkcji zielonej energii z upraw wierzby energetycznej, z uwzględnieniem efektów zewnętrznych, dla potencjalnej wielkości uprawy o powierzchni 6000 ha.

${ }^{34}$ Notowania zielonych certyfikatów na Towarowej Giełdzie Energii, www.wyniki.tge.pl.

35 R. Wacławowicz, Rolnicze wykorzystanie popiołów ze spalania biomasy, www.biomasa. org (01.06.2014).

${ }^{36}$ Obwieszczenie Ministra Środowiska, z dnia 13 sierpnia 2013 r. w sprawie wysokości stawek opłat za korzystanie ze środowiska na rok 2014, Monitor Polski z dnia 10 września 2013 r., poz. 729.

${ }^{37}$ P. Krawczyk, J. Szczygiel, Analiza uwarunkowań stosowania paliwa alternatywnego do wytwarzania energii elektrycznej i cieplnej w warunkach przedsiębiorstwa ciepłowniczego, Rynek energii 6/2013.

${ }^{38}$ Dane Kogeneracji S.A., czerwiec 2014.

39 Dane Kogeneracja S.A. czerwiec 2014. 
Tabela 1. Zestawienie kosztów i korzyści zastąpienia węgla kamiennego wierzbą energetyczną pozyskaną z obszaru 6000 ha

\begin{tabular}{|c|c|c|c|c|c|c|}
\hline \multirow[b]{2}{*}{ Lp. } & & \multicolumn{2}{|c|}{ Zmienna } & \multicolumn{2}{|c|}{ Koszt jednostkowy } & \multirow{2}{*}{$\begin{array}{l}\text { Koszty/ } \\
\text { korzy- } \\
\text { ści dla } \\
6000 \text { ha } \\
\text { [mln zl/ } \\
\text { rok] }\end{array}$} \\
\hline & & $\begin{array}{c}\text { wartość } \\
\text { jednost- } \\
\text { kowa }\end{array}$ & $\begin{array}{l}\text { jednost- } \\
\text { ka }\end{array}$ & cena & $\begin{array}{c}\text { jednost- } \\
\text { ka }\end{array}$ & \\
\hline 1. & Sadzonki & 6000 & ha & 666,6 & zł/ha/rok & $-4,0$ \\
\hline 2. & $\begin{array}{l}\text { Prowadzenie plantacji, w tym } \\
\text { utrata zasobu-wody }\end{array}$ & 6000 & ha & 500 & $\mathrm{zl} / \mathrm{ha} /$ rok & $-3,0$ \\
\hline 3. & $\begin{array}{l}\text { Wykorzystanie osadów ście- } \\
\text { kowych }\end{array}$ & 20 & $\begin{array}{l}\mathrm{Mg} / \mathrm{ha} / \\
\text { rok }\end{array}$ & 20 & $\begin{array}{l}\text { zł/Mg } \\
\text { osadów }\end{array}$ & 2,4 \\
\hline 4. & Rekultywacja & 6000 & ha & 300 & $\mathrm{zt} / \mathrm{ha} /$ rok & $-1,8$ \\
\hline 5. & Ograniczenie emisji $\mathrm{CO}_{2}$ & 27600 & $\mathrm{Mg} /$ rok & 24 & $\begin{array}{c}\mathrm{zt} / \mathrm{Mg} \\
\mathrm{CO} 2\end{array}$ & $0,7^{*}$ \\
\hline 6. & Zielone certyfikaty & 166666 & $\mathrm{MWh} / \mathrm{rok}$ & 214,1 & $\mathrm{zl} / \mathrm{MWh}$ & 17,3 \\
\hline 7. & $\begin{array}{l}\text { Różnica kosztów zakupu pa- } \\
\text { liwa }\end{array}$ & - & & - & & $-4,8$ \\
\hline 8. & Redukcja ilości popiołów & 4890 & $\mathrm{Mg} /$ rok & 19,46 & $\mathrm{zl} / \mathrm{Mg}$ & 0,1 \\
\hline 9. & LĄCZNIE & & & & & 6,8 \\
\hline 10. & $\begin{array}{l}\text { LACCZNIE (procesy spalania } \\
\text { i ich konsekwencje)- poz. 5-8 }\end{array}$ & & & & & 13,2 \\
\hline 11. & Dodatkowe koszty/korzyści & & & & & \\
\hline 12. & $\begin{array}{l}\text { Monokultury i ograniczenie } \\
\text { bioróżnorodności }\end{array}$ & & & - & & \\
\hline 13. & Korozja kotłów & & & - & & \\
\hline 14. & Emisja $\mathrm{O}_{2}$ & & & + & & \\
\hline
\end{tabular}

* W procesach spalania w układach ko generacyjnych, ok. $15 \%$ emisji $\mathrm{CO}_{2}$ przedostaje się do atmosfery. Pozostała ilość jest wychwytywana w procesach oczyszczania. Jednak z punktu widzenia kosztów zewnętrznych produkty powstające w procesach oczyszczania również stanowią koszt. $Z$ tego też względu, dla uproszczenia wyliczeń, przyjęto, że cała emisja $\mathrm{CO}_{2}$ trafia do powietrza.

Źródto: opracowanie własne.

Zestawienie omówionych kosztów i korzyści wskazuje, że wykorzystanie wierzby energetycznej zamiast węgla kamiennego w elektrociepłowni w celu wyprodukowania 600000 GJ energii rocznie, pozwoliłoby na zaoszczędzenie blisko 7 mln złotych. Koszty te przekładają się na cenę energii, a więc korzyści dla ostatecznych odbiorców i poprawy jakości życia. Analizując jedynie koszty i korzyści związane ze spalaniem węgla i wierzby energetycznej, korzyści rosną o blisko $50 \%$ i wynoszą ponad $13 \mathrm{mln}$ zł rocznie. Największe korzyści generuje tu jednak 
zastosowanie przez państwo instrumentu wsparcia zastosowania OZE, zielonych certyfikatów. Co w kontekście konieczności spełniana założonych celów środowiskowych dotyczących redukcji emisji gazów cieplarnianych i zastosowania OZE w sektorze energetycznym, znajduje uzasadnienie. Sama sprzedaż nadwyżki uprawnień zbywalnych nie zrekompensuje wyższych kosztów zakupu biomasy, ani tym bardziej kosztów jej uprawy.

\section{Oszacowanie kosztu energii wyprodukowanej z odpadów komunalnych}

Około 90\% wytworzonych komunalnych odpadów zmieszanych, mogłoby stanowić podstawowe paliwo dla elektrociepłowni bez zagrożenia sezonowością dostaw. Wykorzystanie takiego paliwa wymaga jednak dostosowania instalacji, a więc i znacznych nakładów finansowych. Tym samym elektrociepłownia staje się instalacją termicznego unieszkodliwiania odpadów. Dlatego też uzyskuje przychody z dostarczanych do spalania odpadów. W chwili obecnej zakłady termicznego unieszkodliwiania odpadów są najdroższymi instalacjami unieszkodliwiania odpadów. Koszt przyjęcia odpadów do zakładu termicznego przekształcania odpadów sięga $750 \mathrm{zł} / \mathrm{Mg}^{40}$ podczas, gdy przyjęcie na składowisko to koszt 190 - 333 zł/Mg $/ \mathrm{Mg}^{41}$. Przyjęto, że odpady będą wcześniej homogenizowane i suszone. Koszt takich działań przyjęto na poziomie około $60 \mathrm{zł} / \mathrm{Mg}^{42}$. W dalszych wyliczeniach przyjęto koszt przyjęcia na instalację na poziomie średniej ceny przyjęcia na składowisko, pomniejszonej o koszt wcześniejszego przygotowania, tj. $200 \mathrm{zz} / \mathrm{Mg}$.

Na analizowanym obszarze pięciu województw wytwarza się rocznie około $5 \mathrm{mln} \mathrm{Mg}$ odpadów komunalnych. Zatem w elektrociepłowni mogłoby być spalanych około $70 \%$ tych odpadów (przyjęto, że 30\% to zbiórka odpadów zebranych selektywnie). Około $40 \%$ pozostałych odpadów to odpady biodegradowalne. Uzyskana z nich energia elektryczna stanowi energię ze źródeł odnawialnych i uzyskuje zielone certyfikaty. Zatem z wytworzonych odpadów, 3,5 mln Mg może zostać spalone, z czego 1,4 mln Mg może stanowić źródło energii odnawialnej, o ile zostanie z nich wyprodukowana energia elektryczna. Przyjęto, że wartość opałowa zmieszanych odpadów komunalnych wynosi $10 \mathrm{GJ} / \mathrm{Mg}$, a odpadów biodegradowalnych $11,6 \mathrm{GJ} / \mathrm{Mg}^{43}$. Zatem można wytworzyć 37,2 mln GJ rocznie energii, z czego 16,2 mln GJ rocznie zielonej

${ }^{40}$ MPO Warszawa, spalarnia na Targówku.

$41190 \mathrm{zł} / \mathrm{Mg}$ to cena przyjęcia odpadów w MPWiK w Lublinie, a 333 zł/Mg to cena w Zakładzie Zagospodarowania Odpadów w Poznaniu Sp. Z o.o.

${ }^{42}$ Szacunki własne, na podstawie kosztów zakładów MBP.

${ }^{43}$ Wartości opałowe (WO) i wskaźniki emisji $\mathrm{CO}_{2}$ (WE) w roku 2011 do raportowania w ramach Wspólnotowego Systemu Handlu Uprawnieniami do Emisji za rok 2014, KOBIZE, grudzień 2013. 
energii, przy założeniu, że w układzie kogenaracyjnym energia elektryczna stanowi $40 \%{ }^{44}$. Przy tych założeniach, przychód z tytułu przyjęcia odpadów do elektrociepłowni wynosi $700 \mathrm{mln}$, a wartość praw majątkowych z tytułu zielonych certyfikatów, wynosi blisko $1012,6 \mathrm{mln}$ zł/rok ${ }^{45}$. Żeby wytworzyć analogiczną ilość energii, co z odpadów, należy spalić 1773333 Mg węgla o wartości opałowej $21 \mathrm{GJ} / \mathrm{Mg}$. Zatem różnica w cenie zakupu paliwa wynosi $1294 \mathrm{mln} \mathrm{zł}^{46}$. Wskażniki emisji $\mathrm{CO}_{2}$ są następujące: dla odpadów biodegradowalnych: 11,6 GJ/Mg, a dla odpadów pozostałych: $10 \mathrm{GJ} / \mathrm{Mg}$. Zatem emisja $\mathrm{CO}_{2}$ ze spalania odpadów wynosi 3,5 $\mathrm{mln} \mathrm{Mg} \mathrm{CO}_{2}$. Emisja $\mathrm{CO}_{2}$ ze spalania węgla, w celu wytworzenia tej samej ilości energii, jest na tym samym poziomie (WE wynosi 93,87 kg/GJ) ${ }^{47}$. Spalając 70\% odpadów komunalnych, redukowana jest emisja gazu składowiskowego, przyjęto, że o taką samą wartość. Emitowany gaz to mieszanina głównie metanu (35-60\%) i ditlenku węgla (35-55\%), powstająca $\mathrm{w}$ wyniku beztlenowej biodegradacji organicznej frakcji odpadów. Różnice w składzie zależą przede wszystkim od wieku składowiska, stanu rozkładu odpadów, klimatu, wilgotności, czy składu morfologicznego odpadów. Wartość opałowa biogazu ${ }^{48}$ zależna jest od procentowego udziału metanu w jego składzie, średnio wynosi około $22 \mathrm{MJ} / \mathrm{m}^{3}$, ale w Polsce w niewielkim stopniu jest on wykorzystywany w celach energetycznych, zatem w analizie przyjęto, że cały gaz trafia do atmosfery. Średnia emisja gazu składowiskowego wynosi $700 \mathrm{~m}^{3} / \mathrm{h} \mathrm{z} 1000000 \mathrm{Mg}$ odpadów. Zatem z analizowanych składowisk emitowanych jest $2450 \mathrm{~m}^{3} / \mathrm{h}$ gazu, a więc $1151,5 \mathrm{~m}^{3} / \mathrm{h}$ metanu (średnio 47\%) i 1102,5 m³ $/ \mathrm{h}$ ditlenku węgla (średnio 45\%). Czyli $19000 \mathrm{Mg}$ $\mathrm{CO}_{2}$ rocznie (gęstość $\mathrm{CO}_{2}$ wyn. $1,96 \mathrm{~kg} / \mathrm{m}^{3}$ ) i $7200 \mathrm{Mg} \mathrm{CH}_{4}$ (gęstość $\mathrm{CH}_{4}$ wyn. $0,72 \mathrm{~kg} / \mathrm{m} 3)$. Przeliczając te emisje na $\mathrm{CO}_{2}$ ekwiwalentny należy zastosować wskaźniki Potencjału Globalnego Ocieplenia (GPW) dla $\mathrm{CO}_{2}: 1$ i dla $\mathrm{CH}_{4}: 21$ [100 lat, $\left.\mathrm{CO}_{2} \mathrm{e}\right]^{49}$. Czyli emisja $\mathrm{CO}_{2}$ ekwiwalentnego wynosi łącznie $171447 \mathrm{Mg}$ /rok. Bilansując emisje $\mathrm{CO}_{2}$ ze spalania węgla, odpadów i emisji gazu składowiskowego, zamieniając węgiel kamienny na odpady, redukujemy emisję $\mathrm{CO}_{2}$ o $120000 \mathrm{Mg}$ rocznie (70\% emisji gazu składowiskowego).

Spalając 3,5 mln Mg odpadów komunalnych pozostaje 6,5\% masy (tj. $227500 \mathrm{Mg}$ rocznie) odpadów, które muszą być składowane na składowisku.

${ }^{44}$ Rozporzadzenie Ministra Środowiska z dnia 20 grudnia $2005 \mathrm{r}$. w sprawie standardów emisyjnych instalacji, (Dz.U. 2005, Nr 260, poz. 2181).

45 14000000GJ=4200000MWh; 420000MWh*241,1 zł/MWh=1012,6 mln zł.

${ }^{46}$ Przychód z przyjęcia odpadów wynosi $700 \mathrm{mln}$ zł/rok, a koszt zakupu węgla 55,8 mln zł/ rok, w ilościach odpowiadających wytworzeniu tej samej ilości energii.

${ }^{47}$ Wartości opałowe (WO) i wskaźniki emisji $\mathrm{CO}_{2}$ (WE) w roku 2011 do raportowania w ramach Wspólnotowego Systemu Handlu Uprawnieniami do Emisji za rok 2014, KOBIZE, grudzień 2013.

${ }^{48}$ P. Sołowiej, M. Neugebauer, Energetyczne wykorzystanie gazu wysypiskowego na przyktadzie obiektu, [w:] „Inżynieria Rolnicza”, Uniwersytet Wamińsko-Mazurski, Olsztyn 6/104 2008, s. 182.

49 IPCC (SAR). 
Ale włączając w to żużle i popioły, to pozostałości po spalaniu odpadów wynoszą około $30 \%$ ich masy ${ }^{50}$. Zatem w wyniku spalania odpadów powstaje $660000 \mathrm{Mg}$ / rok więcej pozostałości niż w wyniku spalania węgla kamiennego.

Wykorzystanie paliwa z odpadów w elektrociepłowniach, wymaga poniesienia znaczących nakładów inwestycyjnych w celu przystosowania zakładu energetycznego do spalania takiego paliwa, głównie pod kątem spełniania norm środowiskowych. Zaadoptowanie istniejącej elektrociepłowni to koszt około 170250 euro/Mg planowanej wydajności (do dalszych obliczeń przyjęto 230 euro/ $\mathrm{Mg}$ ), przy czym wydajność musi wynosić co najmniej $100000 \mathrm{Mg} / \mathrm{rok}^{51}$. Zmiany takie są tańszą alternatywą dla budowania spalarni odpadów komunalnych, której koszty inwestycyjne szacuje się na 500-700 euro/ $\mathrm{Mg}^{52}$. Rozpatrując sytuację taką, że przystosowujemy elektrociepłownie i nie budujemy spalarni, możemy zaoszczędzić $1295 \mathrm{mln}$. Biorąc pod uwagę fakt, że spalarnie liczy się na 30 lat, uniknięty roczny koszt inwestycyjny wynosi $43,1 \mathrm{mln}$ zł/rok. Koszty te są szacowane w oparciu o założenia, że koszty dostosowania są takie same, bez względu na lokalizację i inne czynniki.

Wykorzystując odpady jako paliwo pozbywamy się uciążliwych instalacji unieszkodliwiania odpadów, jakim są składowiska. Składowiska w istotny sposób oddziałują na środowisko. Do najważniejszych oddziaływań należy zaliczyć:

- niszczenie krajobrazu,

- emisja gazu składowiskowego i odorów,

- emisja odcieków,

- zagrożenie bakteriologiczne,

- rozwiewanie pyłów i drobnych frakcji odpadów.

Skutkami tych oddziaływań są:

- zanieczyszczenia wód i gleb,

- spadek wartości nieruchomości znajdujących się w rejonie oddziaływania,

- ryzyko wybuchu i zagrożenie dla życia i zdrowia pracowników,

- efekt cieplarniany,

- niszczenie systemu korzeniowego roślin przez penetrujący gaz składowiskowy,

- wzmożone zachorowania ludzi i zwierząt,

- zwiększone rozmnażanie się gryzoni i ptaków żerujących na składowisku.

Przyjmując założenie, podobnie jak w odniesieniu do pozostałych skutków środowiskowych, że wprowadzone narzędzia ekonomiczne polityki ochrony środowiska odzwierciedlają wartość efektów zewnętrznych, do dalszej wyceny przyjęto stawkę opłaty za przyjęcie Mg odpadów zmieszanych na środowisko. Zatem

${ }^{50}$ G. Wielgosiński, Wtórne odpady ze spalania odpadów komunalnych. Bariery i perspektywy ich wykorzystania, Politechnika łódzka, Wydział inżynierii procesowej i ochrony środowiska, s. 3 i s. 10, https://www.mos.gov.pl/g2/big/2012_02/c54c6691a1004ecf921596c96aa74987.pdf.

${ }^{51}$ T. Pająk, Energetyczne wykorzystanie odpadów komunalnych, [w:] Poradnik-odnawialne i niekonwencjonalne źródła energii, red. Gałuszko M., Kraków-Tarnobrzeg 2008, s. 646.

52 Tamże. 
uniknięty koszt zewnętrzny funkcjonowania składowisk wynosi $419 \mathrm{mln}$ zł/rok (stawka za zmieszane odpady komunalne $282,17 \mathrm{zt} / \mathrm{Mg}$ ) ${ }^{53}$.

Tabela 2. Zestawienie kosztów i korzyści zastąpienia węgla kamiennego odpadami komunalnymi z analizowanego obszaru

\begin{tabular}{|c|c|c|c|c|c|c|}
\hline \multirow[b]{2}{*}{ Lp. } & & \multicolumn{2}{|c|}{ Zmienna } & \multicolumn{2}{|c|}{$\begin{array}{c}\text { Koszt } \\
\text { jednostkowy }\end{array}$} & \multirow{2}{*}{$\begin{array}{c}\text { Koszty/korzyści } \\
\text { dla 3,5 MLN Mg } \\
\text { odpadów kom. } \\
\text { [mln zl/rok] }\end{array}$} \\
\hline & & $\begin{array}{c}\text { wartość jed- } \\
\text { nostkowa }\end{array}$ & jednostka & cena & jednostka & \\
\hline 1. & $\begin{array}{l}\text { Uniknięty koszt skła- } \\
\text { dowania odpadów }\end{array}$ & & & & & 419 \\
\hline 2. & $\begin{array}{l}\text { Dostosowanie zakladu } \\
\text { w stosunku do budowy } \\
\text { spalarni }\end{array}$ & - & - & - & - & 43,1 \\
\hline 3. & $\begin{array}{l}\text { Nadwyżka uprawnień } \\
\text { zbywalnych - ograni- } \\
\text { czenie emisji } \mathrm{CO}_{2}\end{array}$ & 120000 & $\mathrm{Mg} /$ rok & 24 & $\mathrm{z} / \mathrm{Mg} \mathrm{CO}_{2}$ & 2,9 \\
\hline 4. & Zielone certyfikaty & 4200000 & MWh/rok & 214 & zł/MWh & 1174 \\
\hline 5. & $\begin{array}{l}\text { Różnica kosztów zaku- } \\
\text { pu paliwa }\end{array}$ & - & & - & & 1294 \\
\hline 6. & Ilość popiołów & 660000 & $\mathrm{Mg} /$ rok & 19,5 & $\mathrm{zl} / \mathrm{Mg}$ & $-12,8$ \\
\hline 7. & LĄCZNIE & & & & & 2920,1 \\
\hline 8. & $\begin{array}{l}\text { LACCZNIE (procesy } \\
\text { spalania i ich konse- } \\
\text { kwencje) - poz. 3-6 }\end{array}$ & & & & & 2458,0 \\
\hline
\end{tabular}

Źródto: opracowanie własne.

Analizując tabelę należy jednoznacznie stwierdzić, że zastosowanie odpadów w elektrociepłowniach daje bardzo wysokie korzyści zewnętrzne, prawie $3000 \mathrm{mln}$ zł rocznie, przy produkcji energii w ilości 37240000 GJ rocznie. Zastępując węgiel kamienny, odpadami komunalnymi niezaprzeczalną korzyścią, której nie daje żaden inny rodzaj paliwa, są korzyści społeczne w postaci unikniętych kosztów zewnętrznych funkcjonowania składowisk. Inną, to ciągła dostępność tego paliwa bez ryzyka sezonowości i wykazująca rosnącą zależność od dochodów mieszkańców (podobnie jak konsumpcja energii). Podobnie jak w przypadku zastąpienia przez wierzbę, jedne z największych korzyści w zakresie procesów spalania i ich konsekwencji, dają zielone certyfikaty.

${ }^{53}$ Załącznik nr 1 do Obwieszczenie Ministra Środowiska z dnia 13 sierpnia 2013 r. w sprawie wysokości stawek opłat za korzystanie ze środowiska na rok 2014, poz. 729, s. 2. 
Podobnie dużą korzyścią jest też brak kosztów z tytułu zakupu węgla i przychodu z tytułu przyjęcia odpadów na instalację unieszkodliwiania, bo taką staje się zmodernizowana elektrociepłownia. Nakłady inwestycyjne na dostosowanie elektrociepłowni stają się korzyściami, gdyż są to uniknięte koszty budowy spalarni, które muszą powstać, aby spełnić przyjęte przez Polskę zobowiązania. Przyjęto tu uproszczenie polegające na założeniu, że wszystkie odpady, poza surowcowymi, będą poddawane termicznemu unieszkodliwianiu, a więc spalarni musi być na tyle dużo, aby były w stanie przyjąć wszystkie te odpady.

\section{Podsumowanie}

Wykorzystując istniejące zasoby na analizowanym obszarze-wytwarzaną ilość odpadów oraz areał możliwy do wykorzystania pod uprawy wierzby energetycznej, należy stwierdzić, że energetyczne wykorzystanie odpadów daje wielokrotnie większą oszczędność zasobu nieodnawialnego, jakim jest węgiel kamienny, prawie 56 krotnie. Pozwala też na wyprodukowanie 62 krotnie większej ilości energii oraz na 97 krotnie więcej energii zielonej. Szczegółowo, ilustruje to tabela 3.

Tabela 3. Porównanie korzyści z zastąpienia węgla kamiennego wierzbą i odpadami komunalnymi

\begin{tabular}{|l|c|c|}
\hline & Węgiel/wierzba & Węgiel/odpady \\
\hline Ilość potencjalnie wyprodukowanej energii [GJ/rok] & 600000 & 37240000 \\
\hline Ilość zaoszczędzonego węgla & 28600 & 1600000 \\
\hline Ilość zielonej energii & 166666 & 16240000 \\
\hline Lączne korzyści [mln zl/rok] & 6,8 & 2920,1 \\
\hline Lączne korzyści procesów spalania [mln zl/rok] & 13,2 & 2458,0 \\
\hline Korzyści 1 GJ [mln zl/rok] & $\mathbf{1 1 , 3}$ & $\mathbf{7 8 , 4}$ \\
\hline Korzyści procesów spalania dla 1 GJ [mln zl/rok] & $\mathbf{2 2 , 0}$ & $\mathbf{6 6 , 0}$ \\
\hline
\end{tabular}

Źródto: opracowanie własne.

Wykorzystanie potencjalnych możliwości na analizowanym obszarze, wyprodukowania energii z wierzby energetycznej pozwala na zaoszczędzenie $28600 \mathrm{Mg}$ węgla kamiennego, o wartości opałowej $21 \mathrm{MJ} / \mathrm{Mg}$. Wykorzystanie odpadów komunalnych wytwarzanych na analizowanym obszarze pozwala natomiast zaoszczędzić $1600000 \mathrm{Mg}$ węgla kamiennego o tych samych parametrach. Korzyści zewnętrzne produkcji 1 GJ energii przy wykorzystaniu odpadów jako zamiennika węgla są 7 krotnie większe niż przy wykorzystaniu wierzby. Natomiast analogiczne korzyści, ale dotyczące tylko procesów spalania są 3 krotnie większe 
w stosunku do odpadów w porównaniu z wierzbą. Te wielkości jednoznacznie wskazują, że państwo powinno opracować skuteczny system wsparcia dla dostosowywania elektrociepłowni do spalania odpadów. Wykorzystanie biomasy również przynosi pewne korzyści społeczne i środowiskowe, ale wiąże się też z kosztami, a przede wszystkim nie daje takie potencjału produkcji energii. Ponadto wykorzystanie odpadów rozwiązuje szereg problemów (przynajmniej częściowo) związanych z gospodarką odpadami. Mimo radykalnej przebudowy systemu gospodarki odpadami i wzrostu jego kosztów, występuje w Polsce niewystarczająca ilośc instalacji oraz nadmierna podaż paliwa RDF w stosunku do popytu ze stony jedynego odbiorcy - cementowni. Dlatego spalanie lub współspalanie odpadów przez elektrociepłownie byłoby bardzo pożądanym kierunkiem. Uwzględnienie korzyści i/lub kosztów zewnętrznych w rachunku opłacalności stosowania tego paliwa mogłoby się przyczynić do modyfikacji polskiego prawa i poprawy ekonomicznej opłacalności jego stosowania.

\section{Literatura}

Agencja Restrukturyzacji i Modernizacji Rolnictwa Zalesienie gruntów rolnych oraz zalesienie gruntów innych niż rolne. Załącznik nr 15 Metodologia kalkulacji płatności dla działania.

Bickel P. Friedrich R., ExternE 05 -Externalities of Energy, Methodology 2005 update, EUR 21951, 2005.

Brando M., Cylwik A., Elżanowski F.,. Kucińska A., Kulesa M., Dostosowanie systemu wsparcia dla energii elektrycznej pochodzacej z odnawialnych źródet energii do zmian zachodzacych kosztach wytwarzania energii paliw kopalnych, Warszawa: Ministerstwo Gospodarki, 2009.

Dane firmy Kogeneracji S.A., czerwiec 2014.

Dane firmy MPO Warszawa, spalarnia na Targówku.

Dane firmy MPWiK w Lublinie.

Dane Zakład Zagospodarowania Odpadów w Poznaniu Sp. z o.o.

Dyrektywa Rady 1999/31/WE z dnia 26 kwietnia 1999 r. Dz.Urz. WE L 182 z 16.07.1999, z późn. zm.

Dyrektywa Parlamentu Europejskiego i Rady 2000/76/WE z dnia 4 grudnia 2000 r. Dz.Urz. WE L 332 z 28.12.2000, s. 91, z późn. zm.

Dyrektywa Parlamentu Europejskiego i Rady 2004/8/WE z dnia 11 lutego 2004 r.

Dyrektywa Parlamentu Europejskiego i Rady 2008/98/WE z dnia 19 listopada 2008 r. Dz.Urz. UE L 312 z 22.11.2008.

Dyrektywa Parlamentu Europejskiego i Rady 2009/28/WE z dnia 23 kwietnia 2009 r.

ExternE Homepage. Externalities of Energy. A Research Project of the European Commission, from http://www.externe.info/.

Ile tlenu pochłania las? http://www.focus.pl/nauka/zobacz/publikacje/ile-tlenu-produkuje-las/ i Lasy zamiast filtrów http://www.rp.pl/artykul/555992.html.

Impacts on Health of emissions from Landfill Sites Documents of the Health Protection Agency July 2011.

Główny Urząd Statystyczny Ochrona środowiska 2011, Warszawa 2012.

Główny Urząd Statystyczny rocznik demograficzny 2011, Warszawa 2012.

Główny Urząd Statystyczny Energia ze źródeł odnawialnych w 2012 roku, Warszawa 2013.

KOBIZE grudzień 2013. 
Krajowy Rynek Nieruchomości, http://www.krn.pl/.

Krajowy Plan Działania w zakresie energii ze źródeł odnawialnych, 7 grudnia 2010.

Krajowy Plan Gospodarki Odpadami 2014, Uchwała Rady Ministrów Nr 217 z dnia 24 grudnia 2010 r. w sprawie „Krajowego planu gospodarki odpadami 2014”.

Kudełko M., Koszty zewnętrzne systemów energetycznych, Instytut Gospodarki Surowcami Mineralnymi i Energią PAN, Warszawa 2002.

Krawczyk P., Szczygieł J., Analiza uwarunkowań stosowania paliwa alternatywnego do wytwarzania energii elektrycznej $i$ cieplnej $w$ warunkach przedsiębiorstwa ciepłowniczego, Rynek energii 6/2013.

Lasiewicz A., Oczyszczajaca rola drzew, Program klimatyczny Polskiej Zielonej Sieci 2009.

Majtkowski W., Potencjat upraw energetycznych, badania własności i standaryzacji biopaliw statych, materiały seminaryjne, Europejskie Centrum Energii Odnawialnej, Warszawa 30 czerwca 2003.

Molas R. „Pelet z biomasy” Lublin 2005 r.http://www.pl.scanbio.pl/.

Obwieszczenie Marszałka Sejmu Rzeczypospolitej Polskiej z dnia 14 września 2010 r. Dz.U. Nr 185, poz. 1243 z 2010.

Obwieszczenie Ministra Środowiska, z dnia 13 sierpnia 2013 r. Monitor Polski z dnia 10 września 2013.

Pająk T., Odzysk energii z odpadów a pozostałe cele gospodarki odpadami komunalnymi, [w:] Poradnik - odnawialne i niekonwencjonalne źródła energii, Tarbonus Sp z o.o., Kraków 2008.

Pająk T., Energetyczne wykorzystanie odpadów komunalnych, [w:] Poradnik-odnawialne i niekonwencjonalne źródła energii, Tarbonus Sp. z o.o., Kraków 2008.

Plan Gospodarki Odpadami dla Miasta Wrocławia na lata 2009-2012.

Rowe R., Lang C., Chestnut L., Critical Factors in Computing Externalities for Electricity Resources, Resource and Energy Economics, no 18, Washington, 1996.

Rozporządzenie Ministra Gospodarki z dnia 18 października 2012 r. Dz.U. Nr 0, poz. 1229.

Rozporządzenie Ministra Środowiska z dnia 04 listopada 2008 r. Dz.U. Nr 206, poz. 1291.

Rozporządzenie Ministra Środowiska z dnia 20 grudnia 2005 r. Dz.U. Nr 260, poz. 2181.

Rozporządzenie Ministra Środowiska z dnia 22 kwietnia 2011 r. Dz.U. Nr 95, poz. 558.

Sieciechowicz A., Osady ściekowe na plantacji wierzby energetycznej, Zeszyty Naukowe Uniwersytetu Zielonogórskiego nr 141, Inżynieria środowiska 21, Zielona Góra 2011.

Skorek J., Kalina J., Ocena techniczno-ekonomiczna możliwości realizacji projektów energetycznego wykorzystania biomasy w Polsce, Instytut Doskonalenia Wiedzy o Rynku Energii, IDWE Warszawa 2009.

Sołowiej P., Neugebauer M., Energetyczne wykorzystanie gazu wysypiskowego na przyktadzie obiektu, [w:] „Inżynieria Rolnicza”, Uniwersytet Wamińsko-Mazurski, Olsztyn 6/104 2008.

Ustawa z dnia 28 kwietnia 2011 r., Dz.U. Nr 122, poz. 695.

Ustawa o odpadach z dnia 14 grudnia 2012 r., Dz.U. 2013, poz. 21.

Ustawa Prawo energetyczne 2014.

Wielgosiński G., Wtórne odpady ze spalania odpadów komunalnych. Bariery i perspektywy ich wykorzystania, Politechnika łódzka, Wydział inżynierii procesowej i ochrony środowiska, https:// www.mos.gov.pl/g2/big/2012_02/c54c6691a1004ecf921596c96aa74987.pdf.

Włodarski A., Anatomia szwedzkiego cudu, [w:] „Gazeta Wyborcza”, 23.08.2010 r.

Woś A., Ekonomika odnawialnych zasobów naturalnych, SGH, Warszawa 1995.

Valuation of the external cost and benefits to health and environment of waste management options. Final report for Defra by Enviros Consulting Limited association with EFTEC, December 2004.

Załącznik do uchwały nr 157/2010 Rady Ministrów z dnia 29 września 2010 r. Polityka energetyczna Polski do 2030. 
http://ecosenseweb.ier.uni-stuttgart.de/

http://www.biomasa.org.

http://polskiprzemysl.com.pl/przemysl-energetyczny/zielona-marka/tekst/16/.

http://www.ekowat.pl/index.php?str=technologie/.

http://www.lowcarboneconomy.com/userprofile/toddington/_tips_did_you_know/how_big_is_a_ tonne_of_co $2 / 818 /$.

http://www.handel-emisjami-co2.cire.pl.

http://www.ure.gov.pl/portal/pdb/497/4627/Prezes_URE_oglasza_jednostkowe_oplaty_zastepcze_ dla_kogeneracji_na_rok_2013.htm.

http://polskiprzemysl.com.pl/przemysl-energetyczny/zielona-marka/tekst/16/.

http://www.money.pl/pieniadze/kurs/usd,787.html.

http://www.zasad.friko.pl/.

www.wyniki.tge.pl.

http://www.cire.pl/pliki/2/analizauwarunkowastosowaniapaliwaalternatywnegodowytwarzaniaenergiielektrycznejiciepawwarunkachprzedsibiorstwaciepowniczego.pdf

\section{Streszczenie}

Narastające problemy związane z emisją gazów cieplarnianych, gospodarowaniem zasobami oraz rosnącą ilością wytwarzanych odpadów komunalnych, powodują zaostrzanie przepisów środowiskowych, a te z kolei konieczność poszukiwań nowych rozwiązań. Jednym z największych emitentów $\mathrm{CO}_{2}$ oraz konsumentów zasobu nieodnawialnego, jakim jest węgiel, jest sektor elektrociepłowniczy. Regulacje prawne wymuszają częściowe zastąpienie tego surowca odnawialnymi źródłami energii, uruchamiając bodźcowe instrumenty polityki ochrony środowiska. Analizując jednak dostępne w danym rejonie zasoby (biomasy, odpadów, zasobów kopalnych) oraz generowane efekty zewnętrzne przez energetyczne wykorzystanie tych zasobów, należy zróżnicować systemy wsparcia. Powinny być one adresowane do zasobu, który zapewni bezpieczeństwo energetyczne i w najmniejszym stopniu będzie obciążał środowisko, a więc i społeczeństwo. W artykule przeanalizowano potencjalne energetyczne wykorzystanie wierzby energetycznej uprawianej na dostępnym areale oraz wytwarzane odpady komunalne w województwach dolnośląskim, śląskim, wielkopolskim, małopolskim i opolskim. Uzyskane wartości efektów zewnętrznych wskazują, że korzyści uzyskane z zastąpienia węgla, odpadami komunalnymi są wielokrotnie wyższe (czasem kilkudziesięciokrotnie) niż z zastąpienia wierzba energetyczną. Dodatkowo jeszcze pozwala na uporanie się z problemem gospodarowania odpadami i uniknięcie wysokich kar za niedostosowanie systemu do wymogów unijnych. Jest to wskazanie dla decydentów, że należy tak kształtować przepisy prawne, aby stworzyć bodźce do dostosowywania sektora elektrociepłowniczego do spalania odpadów komunalnych. Tym samym łatwiej będzie spełnić cele środowiskowe z obszaru emisji $\mathrm{CO}_{2}$ i gospodarki odpadami.

Słowa kluczowe: Alternatywne źródła energii (odpady komunalne, biomasa), szacowanie efektów środowiskowych

Numer klasyfikacji JEL: Q42, Q41, Q51 